\title{
The effect of the tramway track construction on the aerosol pollution in Debrecen, Hungary
}

\author{
E. Furu ${ }^{\mathrm{a}, *}$, I. Katona-Szabo $^{\mathrm{b}}$, A. Angyal ${ }^{\mathrm{a}}$, Z. Szoboszlai ${ }^{\mathrm{a}}$, Zs. Török ${ }^{\mathrm{a}}$, Zs. Kertész $^{\mathrm{a}}$ \\ ${ }^{a}$ Hungarian Academy of Science Institute for Nuclear Research, Laboratory of Ion Beam Applications, H-4026 Debrecen, Bem tér 18/C, Hungary \\ ${ }^{\mathrm{b}}$ University of Debrecen, P.O. Box 51, H-4001 Debrecen, Hungary
}

\section{A R T I C L E I N F O}

\section{Article history:}

Received 29 July 2015

Accepted 7 August 2015

Available online $\mathrm{xxxx}$

\section{Keywords:}

Urban aerosol pollution

Tramline construction

$\mathrm{PM}_{2.5}$

$\mathrm{PM}_{10}$

PIXE

\begin{abstract}
A B S T R A C T
In this study the effect of a new tramway track construction on the atmospheric aerosol concentration and composition in Debrecen, Hungary, was investigated. The tramway track construction started in 2011 and it was finished in 2013.

$\mathrm{PM}_{2.5}$ and $\mathrm{PM}_{10}$ daily samples were collected with a Gent type filter unit in an urban background site 2 times a week. In addition, a sampling campaign direct next to the construction site was performed with 2 -stage personal samplers between the $21^{\text {st }}$ and $30^{\text {th }}$ of September, 2011 - four hours a day, during working hours.

We studied the change in concentration and composition of fine and coarse fraction aerosol in comparison with the average of the past 5 years. An additional goal was to investigate the personal aerosol exposure near to the construction sites.

In the urban background site a significant increase could be observed both for the $\mathrm{PM}_{2.5}$ and $\mathrm{PM}_{10}$ concentrations for 2012 and 2013. In the elemental composition the concentration of $\mathrm{Fe}, \mathrm{Mn}, \mathrm{Ni}$, and $\mathrm{Cr}$ increased significantly for the construction period.

The $\mathrm{PM}_{10}$ concentrations measured direct next to the construction site were 10-20 higher than those measured at our urban background site or the data provided by the Hungarian Air Quality monitoring network. Days with very high Pb pollution level $\left(\sim 3000 \mathrm{ng} / \mathrm{m}^{3}\right)$ was also recorded.
\end{abstract}

(c) 2015 Elsevier B.V. All rights reserved.

\section{Introduction}

Atmospheric aerosol pollution is one of the most concerned environmental problems in densely populated urban environments [1]. Atmospheric aerosol particles influence the climate, cause several environmental problems, such as air pollution, acidification of ecosystems, damage to buildings and in addition, they have negative effects on human health [2-7]. In order to regulate the particulate matter (PM) level the EU2008/50/EC directive "On ambient air quality and clean air for Europe" is in force in the member states of Europe, including Hungary, since 2008. However, detailed quantitative information is needed on the sources of PM pollution in order to work out effective mitigation strategies.

The main sources of urban air pollution across Europe were reported as traffic, mineral dust, sea salt and regional scale pollution (e. g. sulphate) $[8,9]$. However, large and medium scale construction and reconstruction works can have significant influence on the air quality level locally, for months or for years.

\footnotetext{
* Corresponding author.
}

In this work we study the effect of a new tramline construction in the city of Debrecen, Hungary which took place between 2011 and 2013.

Debrecen is a second largest city in Hungary with about 200,000 inhabitants. It is situated in the Eastern part of the country $230 \mathrm{~km}$ from the capital, Budapest. The city is located between two landscapes Hajdúhát and Nyírség. The main activity is agriculture in the surrounding areas. Debrecen had 6 tramlines from 1884 to 1970 , but due to the policy of the communist era these were all destroyed but one. From 1970 to 2014 only one tramline was operating. In 2010 the construction of the second tramline was started which was delivered in 2014. The new tramline construction was started with a press conference in March 2010. The ceremony of the kick-off meeting was in September 2010. Thereafter the construction begun with the excavations. The works were paused in 2012. During the pause plants were growing on the excavated track. The abandoned building debris (sand dunes) was exposed to the changing of the weather (wind and rain). After nearly a year of stagnation the building started again in 2013. The test operation of the new trams started in July 2013. Finally the new track was handed over in February 2014 and the new and modern tramcars 
started their works as well. Parallel to the development of the new track the old tram track was also renewed. The map on Fig. 1 shows the old and new tram tracks. Our urban background station is situated $500 \mathrm{~m}$ away from the new tramline, so we had a unique possibility to study the effect of the construction work on the concentration and composition of fine and coarse fraction aerosols in comparison with the average of the past 5 years. With the help of a personal sampler we also investigated the personal aerosol exposure near to the construction sites.

\section{Sampling}

The aerosol sampling was carried out at two locations. One was the garden of the Atomki which is situated about $500 \mathrm{~m}$ from the new tramline (see station no 1 on Fig. 1). Here we collect aerosol samples two times a week since 1988. The samplings were executed with a 2 stage Gent type samplers [10] equipped with Nuclepore polycarbonate filters of $8 \mu \mathrm{m}$ and $0.4 \mu \mathrm{m}$ pore diameters. This way two size fractions were separated: the fine fraction

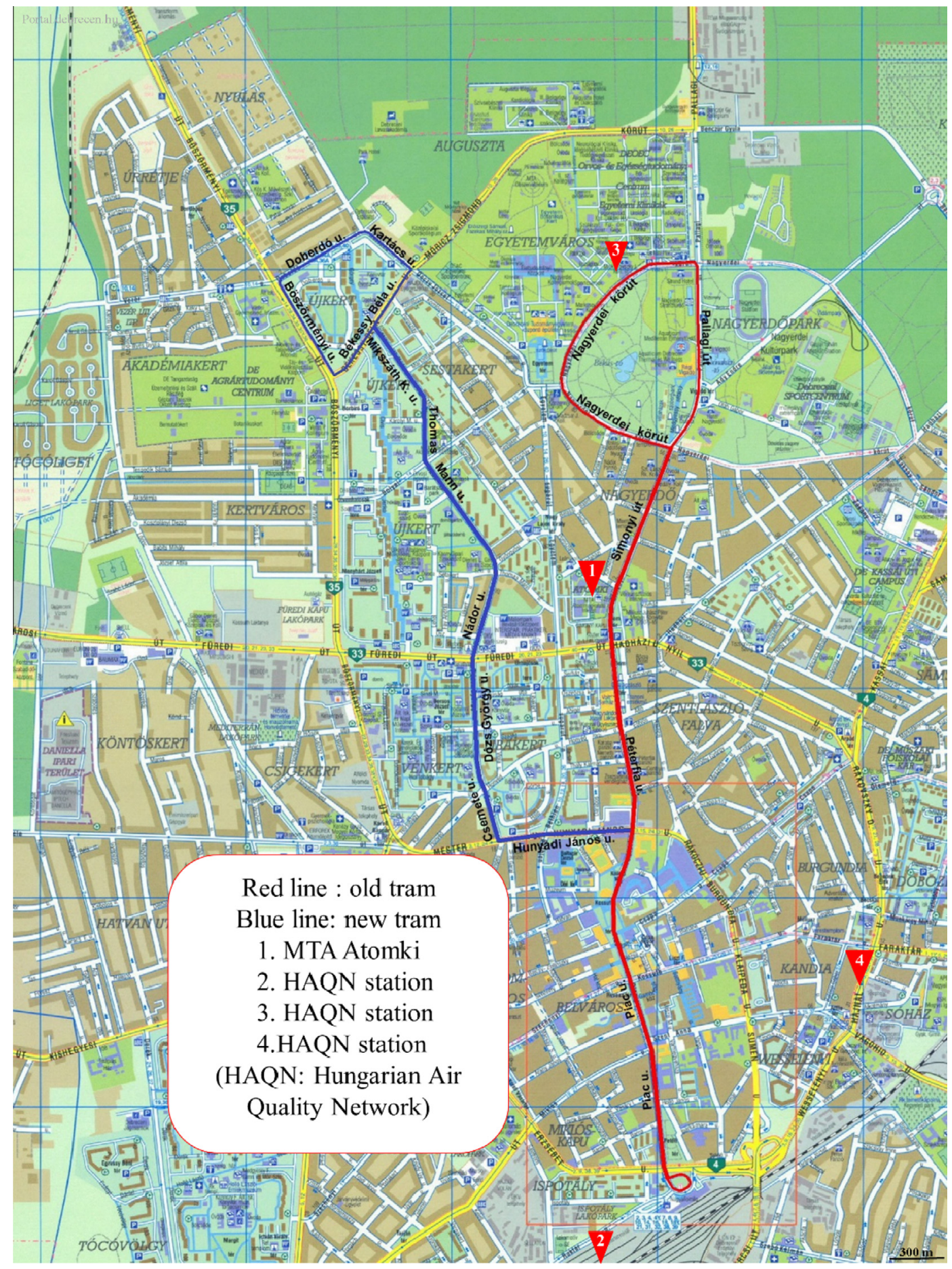

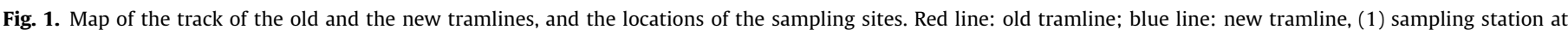

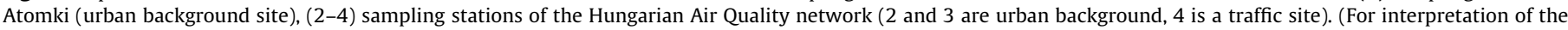
references to color in this figure legend, the reader is referred to the web version of this article.) 
Table 1

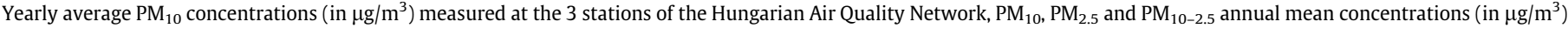
measured at the Atomki station, $\mathrm{PM}_{2.5} / \mathrm{PM}_{10}$ ratios and the annual precipitation ( $\mathrm{mm}$ ) for the years 2006-2014.

\begin{tabular}{|c|c|c|c|c|c|c|c|c|c|}
\hline & 2006 & 2007 & 2008 & 2009 & 2010 & 2011 & 2012 & 2013 & 2014 \\
\hline 4.HAQN - $\mathrm{PM}_{10}$ & 34 & 30 & 33 & 28 & 32 & 35 & 29 & 30 & 34 \\
\hline 2.HAQN $-\mathrm{PM}_{10}$ & 32 & 28 & 30 & 28 & 26 & 33 & 28 & 26 & 26 \\
\hline 3.HAQN $-\mathrm{PM}_{10}$ & 36 & 28 & 28 & 29 & 30 & 34 & 29 & 27 & 29 \\
\hline Atomki - $\mathrm{PM}_{10}$ & 26 & 24 & 25 & 25 & 16 & 25 & 37 & 21 & 22 \\
\hline Atomki $-\mathrm{PM}_{10-2.5}$ & 11 & 11 & 11 & 10 & 7 & 9 & 13 & 7 & 7 \\
\hline Atomki - $\mathrm{PM}_{2.5}$ & 15 & 13 & 14 & 15 & 9 & 15 & 24 & 14 & 14 \\
\hline Atomki $-\mathrm{PM}_{2.5} / \mathrm{PM}_{10}$ & 0.59 & 0.56 & 0.57 & 0.58 & 0.58 & 0.62 & 0.65 & 0.67 & 0.66 \\
\hline Precipitation & 633 & 551 & 551 & 485 & 845 & 442 & 427 & 545 & 456 \\
\hline
\end{tabular}

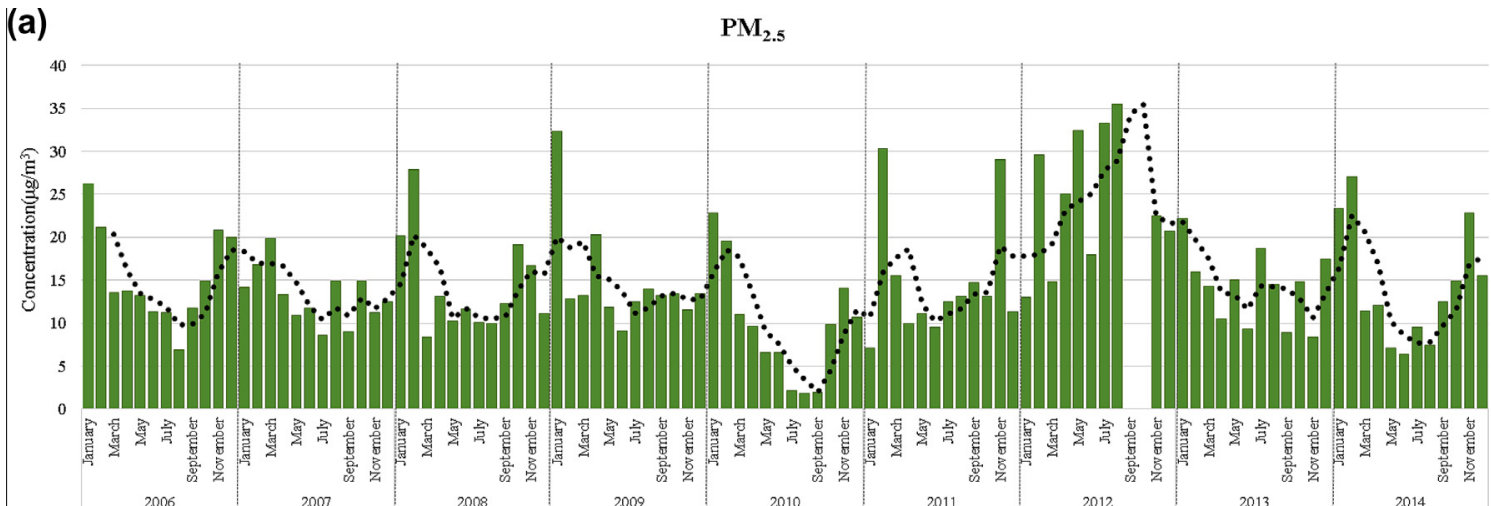

(b)

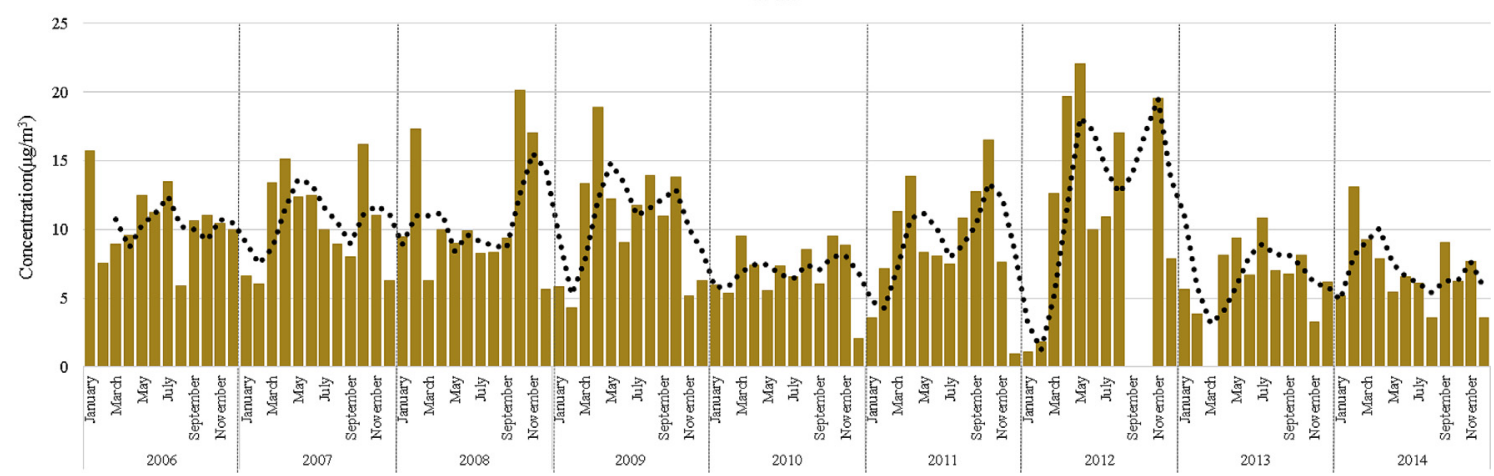

Fig. 2. Monthly average concentrations of $\mathrm{PM}_{2.5}$ (a) and $\mathrm{PM}_{10-2.5}$ (b) for the years 2006-2014. The dotted line corresponds to the moving average of 3 months.

$\left(\mathrm{PM}_{2.5}\right.$ : particles with aerodynamic diameter smaller than $\left.2.5 \mu \mathrm{m}\right)$ and the coarse fraction ( $\mathrm{PM}_{10}-\mathrm{PM}_{2.5}$ : particles with aerodynamic diameter between $2.5 \mu \mathrm{m}$ and $10 \mu \mathrm{m}$ ). The sampler is installed at $4 \mathrm{~m}$ above ground level, on the roof of the IBA Laboratory building.

Table 2

PM mass concentrations measured next to the construction by the personal sampling and the $\mathrm{PM}_{10}$ concentrations measured by the Hungarian Air Quality Network stations in 21-30 September, 2011.

\begin{tabular}{|c|c|c|c|c|c|}
\hline & \multicolumn{2}{|c|}{ The construction } & \multicolumn{3}{|c|}{$\begin{array}{l}\text { Hungarian Air Quality } \\
\text { Network stations } \text { PM }_{10}\end{array}$} \\
\hline & $\begin{array}{l}\mathrm{PM}_{\text {coarse }} \\
\left(\mu \mathrm{g} / \mathrm{m}^{3}\right)\end{array}$ & $\begin{array}{l}\mathrm{PM}_{2.5} \\
\left(\mu \mathrm{g} / \mathrm{m}^{3}\right)\end{array}$ & $\begin{array}{l}\text { 2HAQN } \\
\left(\mu \mathrm{g} / \mathrm{m}^{3}\right)\end{array}$ & $\begin{array}{l}\text { 3HAQN } \\
\left(\mu \mathrm{g} / \mathrm{m}^{3}\right)\end{array}$ & $\begin{array}{l}\text { 4HAQN } \\
\left(\mu \mathrm{g} / \mathrm{m}^{3}\right)\end{array}$ \\
\hline 21.09.2011 & 269 & 24 & 26 & 28 & 24 \\
\hline 22.09 .2011 & 255 & 36 & 45 & 63 & 40 \\
\hline 23.09.2011 & 196 & 36 & 34 & 51 & 26 \\
\hline 26.09.2011 & 283 & 39 & 33 & 48 & 33 \\
\hline 27.09 .2011 & 596 & 51 & 45 & 57 & 43 \\
\hline 28.09.2011 & 365 & 43 & 48 & 49 & 28 \\
\hline 29.09.2011 & 584 & 33 & 26 & 24 & 15 \\
\hline 30.09 .2011 & 519 & 40 & 28 & 41 & 21 \\
\hline
\end{tabular}

The air was pumped through the system with 16-18 1/min flow rate. The total volume of the infiltrated air was measured with a gas-meter. There were no sampling in September and October 2012 due to the reconstruction of the roofs and buildings of Atomki. The other type of aerosol collection was personal sampling. The sample collection was made by walking on the pavement next to the construction on 21-30. September 2011 - four hours a day. The weather was dry and warm on the sampling days. The samplings were carried out with a 2-stage Nuclepore personal sampler equipped with Nuclepore polycarbonate filters with $25 \mathrm{~mm}$ diameter and with $8 \mu \mathrm{m}$ and $0.4 \mu \mathrm{m}$ pore sizes. Thus the fine $\left(\mathrm{PM}_{2.5}\right)$ and coarse (particles with aerodynamic diameter larger than $2.5 \mu \mathrm{m}$ ) particles were collected separately. For this purpose a Buck Elite personal pump was used. The air was pumped through the system with about $3 \mathrm{l} / \mathrm{min}$ flow rate.

\section{Analysis}

Mass concentration of the PM samples was determined by gravimetry. The polycarbonate filters were weighted before and 

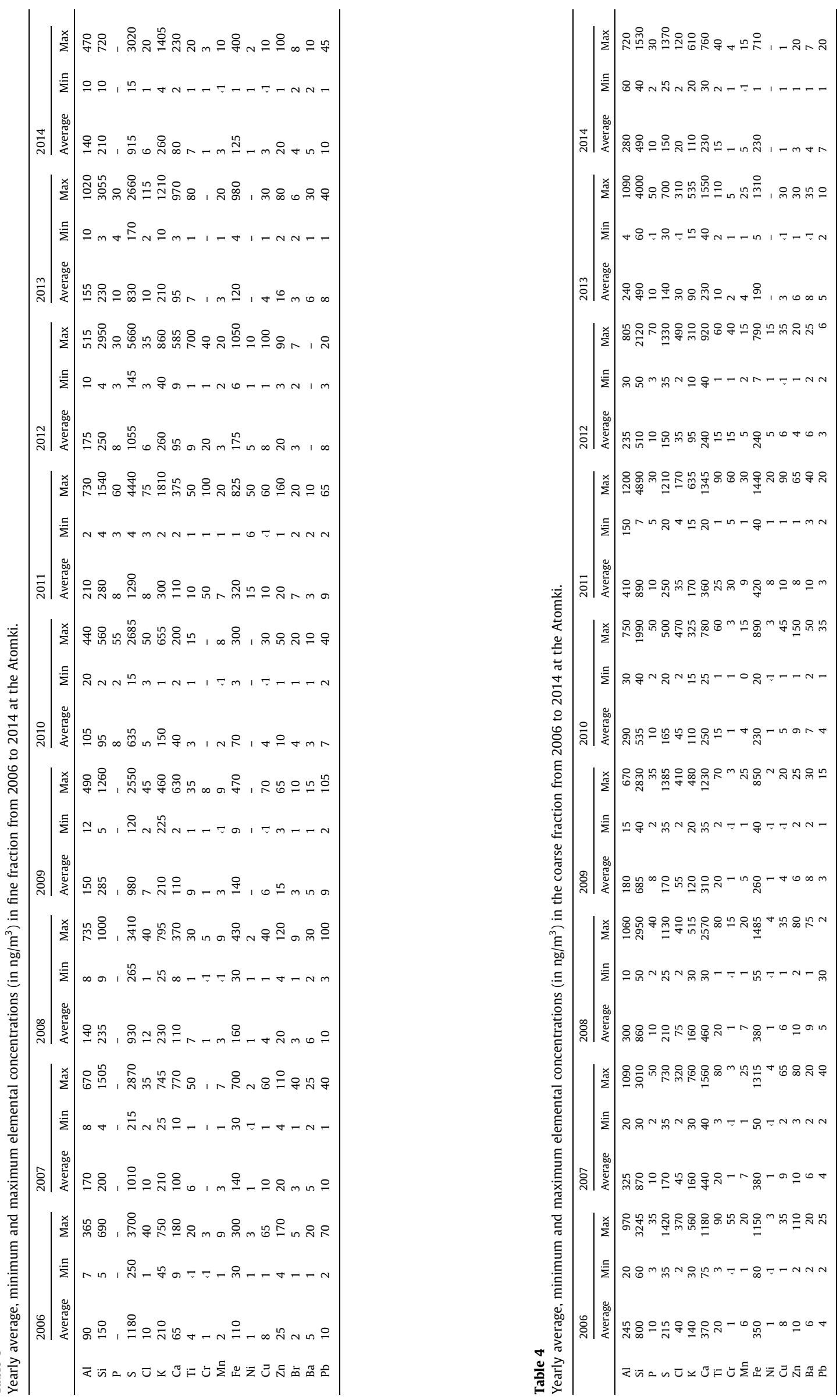
Table 5

PM coarse and $\mathrm{PM}_{2.5}$ elemental concentrations at the construction site by the personal sampling.

\begin{tabular}{|c|c|c|c|c|c|c|c|c|}
\hline & \multicolumn{4}{|c|}{ PM coarse $\left(\mathrm{ng} / \mathrm{m}^{3}\right)$} & \multicolumn{4}{|c|}{ PM fine $\left(\mathrm{ng} / \mathrm{m}^{3}\right)$} \\
\hline & Min & Max & Average & SD & Min & Max & Average & SD \\
\hline $\mathrm{Al}$ & 2710 & 9820 & 5360 & \pm 2270 & 170 & 460 & 325 & \pm 110 \\
\hline $\mathrm{Si}$ & 13,600 & 94,800 & 35,360 & $\pm 25,280$ & 655 & 4720 & 1600 & \pm 1325 \\
\hline$P$ & 40 & 445 & 190 & \pm 120 & 9 & 100 & 20 & \pm 30 \\
\hline$S$ & 490 & 1240 & 780 & \pm 2902 & 440 & 2720 & 1430 & \pm 730 \\
\hline $\mathrm{Cl}$ & 380 & 1020 & 645 & \pm 210 & 30 & 550 & 190 & \pm 180 \\
\hline K & 2090 & 6530 & 3790 & \pm 1450 & 250 & 550 & 385 & \pm 90 \\
\hline $\mathrm{Ca}$ & 6960 & 37,500 & 17,695 & $\pm 11,860$ & 320 & 1850 & 810 & \pm 480 \\
\hline $\mathrm{Ti}$ & 305 & 1110 & 700 & \pm 265 & 15 & 50 & 30 & \pm 10 \\
\hline V & 15 & 40 & 25 & \pm 10 & - & - & - & - \\
\hline $\mathrm{Cr}$ & 10 & 190 & 90 & \pm 50 & 2 & 6 & 3 & \pm 1 \\
\hline Mn & 105 & 350 & 210 & \pm 90 & 10 & 20 & 15 & \pm 3 \\
\hline $\mathrm{Fe}$ & 3930 & 14,400 & 8205 & \pm 3530 & 310 & 875 & 470 & \pm 195 \\
\hline Co & 15 & 50 & 30 & \pm 10 & 4 & 10 & 5 & \pm 3 \\
\hline $\mathrm{Ni}$ & 20 & 50 & 35 & \pm 20 & - & - & - & - \\
\hline $\mathrm{Cu}$ & 20 & 70 & 50 & \pm 20 & 6 & 35 & 20 & \pm 10 \\
\hline $\mathrm{Zn}$ & 70 & 390 & 125 & \pm 110 & 20 & 40 & 30 & \pm 8 \\
\hline $\mathrm{Br}$ & 20 & 30 & 20 & \pm 5 & 20 & 25 & 20 & \pm 3 \\
\hline $\mathrm{Sr}$ & 50 & 155 & 90 & \pm 30 & - & - & - & - \\
\hline $\mathrm{Ba}$ & 150 & 600 & 310 & \pm 145 & 20 & 25 & 20 & \pm 2 \\
\hline $\mathrm{Pb}$ & 30 & 470 & 125 & \pm 145 & 8 & 3255 & 420 & \pm 1150 \\
\hline
\end{tabular}

after the collection. The filters were conditioned for at least $24 \mathrm{~h}$ before weighing in the weighing box at $\sim 25^{\circ} \mathrm{C}$ temperature and $\sim 60 \%$ relative humidity. The elemental composition of the aerosol samples were measured by particle induced X-ray emission (PIXE) analytical method in the Institute for Nuclear Research, Hungarian Academy of Sciences (ATOMKI). The measurement were performed using the PIXE chamber of the IBA Laboratory installed on the left $45^{\circ}$ beamline of the $5 \mathrm{MV}$ Van de Graff accelerator [11]. The irradiation was performed with a $\mathrm{H}^{+}$beam of $2 \mathrm{MeV}$ energy. The beam current was usually 20-50 nA and the measurement time was approximately $15-20 \mathrm{~min}$. The accumulated charge was $40 \mu \mathrm{C}$ on each sample. The obtained X-ray spectra were evaluated with the PIXYKLM program package [12,13]. Concentration of the following elements were assigned: $\mathrm{Al}, \mathrm{Si}, \mathrm{S}, \mathrm{Cl}, \mathrm{K}, \mathrm{Ca}, \mathrm{Sc}, \mathrm{Ti}, \mathrm{V}, \mathrm{Cr}, \mathrm{Mn}, \mathrm{Fe}, \mathrm{Cu}$, $\mathrm{Zn}, \mathrm{Ba}, \mathrm{Pb}$. The values of the concentration were given in $\mathrm{ng} / \mathrm{m}^{3}$. For calculating the elemental concentration values blank corrections were carried out. The error of the determination of the elemental concentration varied between $3 \%$ and $10 \%$, and the detection limit was between 0.2 and $20 \mathrm{ng} / \mathrm{m}^{3}$, depending on the element and its concentration.

\section{Results}

\subsection{Mass concentration}

Table 1 shows the annual average mass concentration of $\mathrm{PM}_{2.5}$, $\mathrm{PM}_{10-2.5}$ and $\mathrm{PM}_{10}$ measured at Atomki, and the annual $\mathrm{PM}_{10}$ concentrations measured by the Hungarian Air Quality Network (stations No. 2-4 on Fig. 1) before and after the years of the construction from 2006 to 2014.

The data of the mass concentration and the precipitation are inverse [14-15]. 2010 was an extremely rainy year, therefore the mass concentration was reduced compared to the other years. In 2006 - 2011 we measured lower $\mathrm{PM}_{10}$ concentrations in the Atomki than the HAQ at their stations. In 2012, the time of the abandoned work site and of the intensive field work, this tendency was reversed. This increase could be explained by the tramline construction. In addition, the contribution of $\mathrm{PM}_{2.5}$ to $\mathrm{PM}_{10}$ increased from $56-58 \%$ to $62-67 \%$ in the years of the construction works. Time series of monthly average $\mathrm{PM}_{2.5}$ and $\mathrm{PM}_{10-2.5}$ are shown in Fig. 2. In 2006-2011 the seasonal variation the $\mathrm{PM}_{2.5}$ concentration shows a maximum in winter and a minimum in summer. In 2012 and 2013 this seasonal trend turned around with summer maximums. Then in 2014 it was again the normal, as before the construction. The concentration of $\mathrm{PM}_{10-2.5}$ shows maximums in autumns and springs for the period of 2006-2011. In 2012 and 2013 summer maximums appeared too. In 2014 it was again the same, as before the construction.

In Table 2 we present the $\mathrm{PM}_{2.5}$ and $\mathrm{PM}_{\text {coarse }}$ mass concentrations measured next to the construction site between 21 and 30 . September 2011 by the personal sampling. The concentration of $\mathrm{PM}_{2.5}$ varied between $24 \mu \mathrm{g} / \mathrm{m}^{3}$ and $51 \mu \mathrm{g} / \mathrm{m}^{3}$. Although the sampling time was only approximately $4 \mathrm{~h}$, as a comparison we mention that the $24 \mathrm{~h}$ limit value of the WHO guideline for $\mathrm{PM}_{2.5}$ is $25 \mu \mathrm{g} / \mathrm{m}^{3}$ [16].

The concentration of the coarse fraction varied between $196 \mu \mathrm{g} /$ $\mathrm{m}^{3}$ and $596 \mu \mathrm{g} / \mathrm{m}^{3}$. In the second week of the sampling the concentration values were nearly double as the values measured in the previous week. This can be attributed to the windy weather conditions on the second week. We compared our data with the $\mathrm{PM}_{10}$ values measured for the same sampling periods by the Hungarian Air Quality Network at their 3 sampling stations. The distance of these sites were about $4 \mathrm{~km}$ from the tramline construction. In every case our values were 8-20 times higher along the construction than the official $\mathrm{PM}_{10}$ data at the distant stations.

\subsection{Elemental concentrations}

For the period of 2006-2014 yearly average, minimum and maximum elemental concentrations are shown in Tables 3 and 4 for the coarse and fine fractions at the Atomki, respectively. Significant changes in the concentration of $\mathrm{Cr}$ and $\mathrm{Ni}$ could be observed in both size fractions. The concentration of $\mathrm{Cr}$ was increased about 40-50-fold in 2011 and about 20-fold in 2012 in both the coarse and the fine fractions. In case of $\mathrm{Ni}$ the increase of the concentration was about 8 times in 2011 and 5 times in 2012. The concentration of iron and manganese also increased, although with much less extent. Time series of $\mathrm{Cr}$ on the coarse fraction and Fe concentrations on the fine fraction can be seen on Fig. 3. The concentration increase appeared with the start of the field works, there was a significant decrease during the stop, and it increased again - to a lesser extent - for the finishing of the construction. The same tendency was observed in the case of coarse fraction $\mathrm{Ni}$, and fine fraction $\mathrm{Mn}$ too. A slight increase (about 
(a)

${ }_{1200} \mathbf{F e}-\mathbf{P M}_{2}$

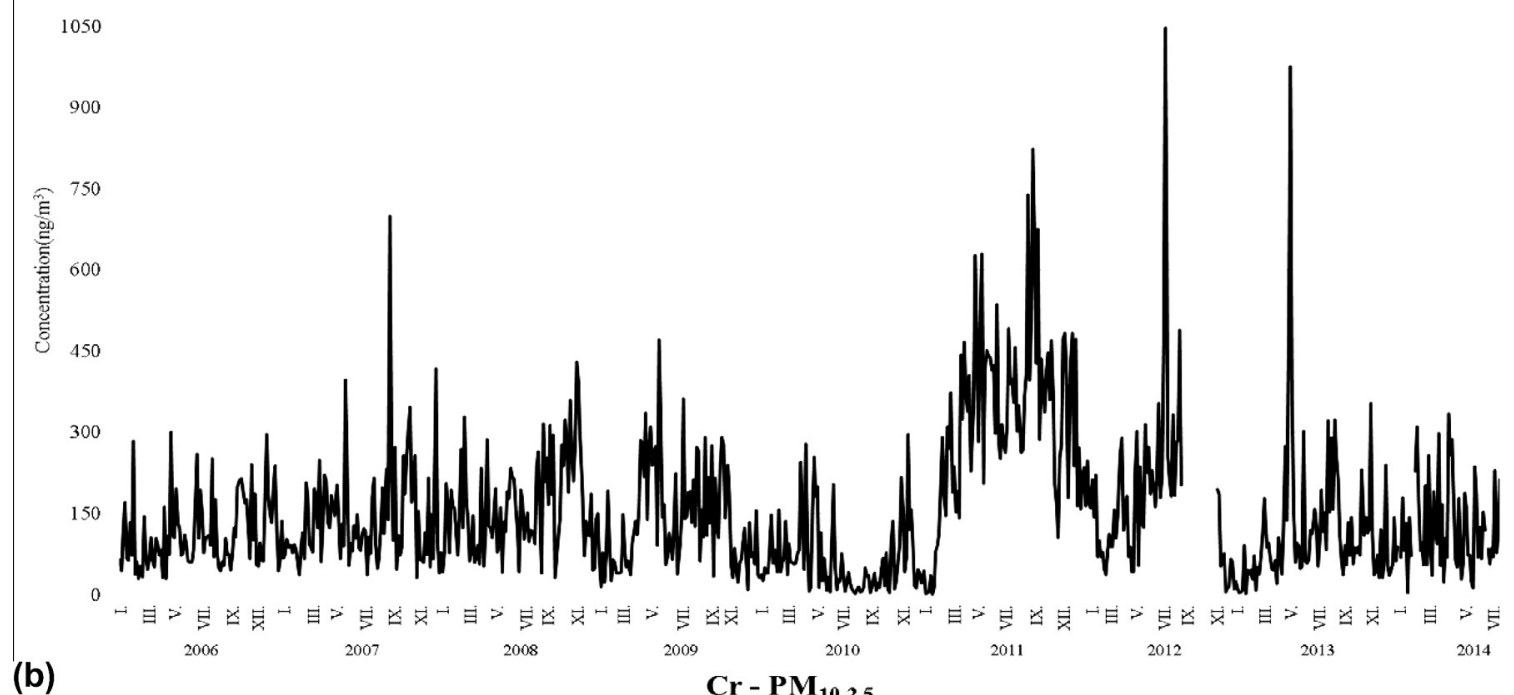

(b)

70

$\mathrm{Cr}-\mathbf{P M}_{10-2.5}$

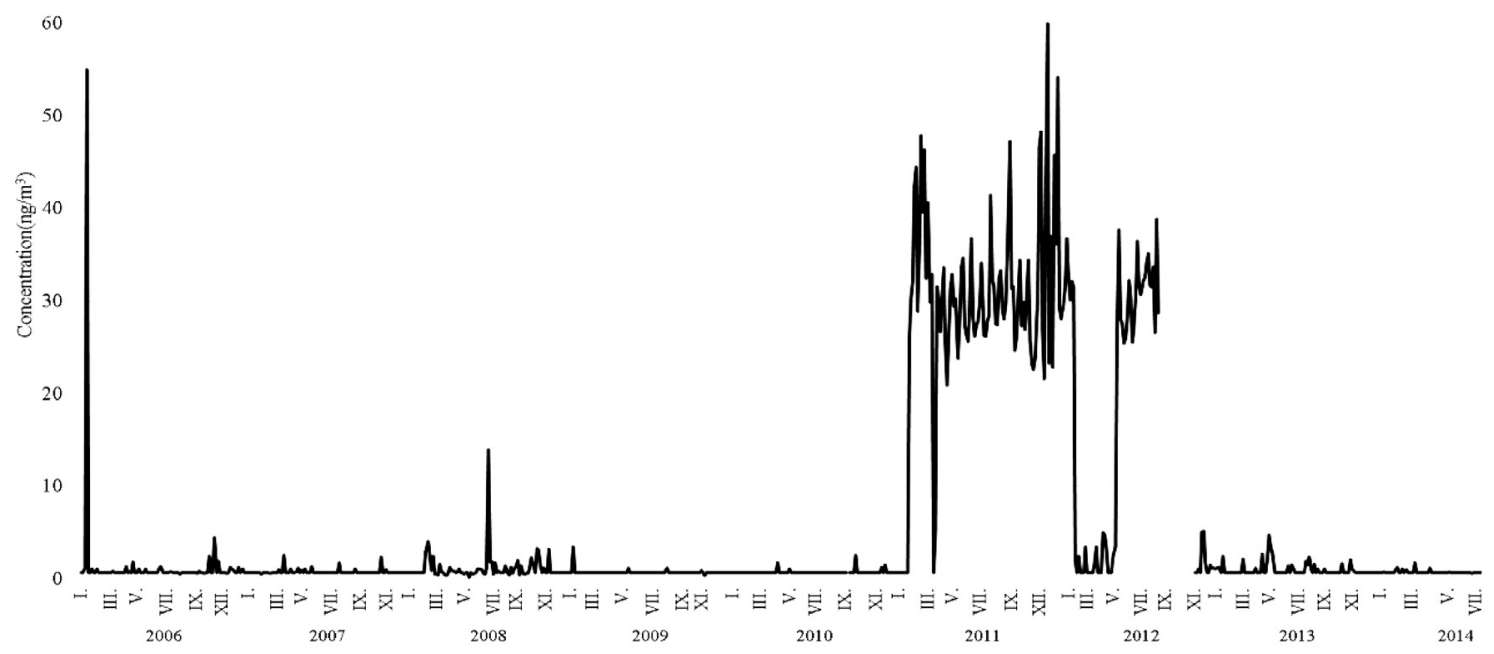

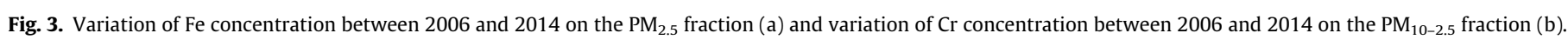

1.5-2 folds) in the concentration of $\mathrm{Cu}$ could be also observed for 2011-2013 in both size fractions. The variation of the other elements were not significant in this period.

Average elemental concentrations, minimum and maximum values are presented in Table 5 for the fine and coarse fractions measured next to the construction site by personal sampling.

In case of the coarse fraction $\mathrm{Si}$ and $\mathrm{Ca}$ were dominant. High concentration of $\mathrm{Al}, \mathrm{K}$, and $\mathrm{Fe}$ was also measured. In case of the coarse fraction we measured about 10 times higher elemental concentrations next to the construction than in the Atomki. These elemental concentration increases were $1.5-2$ folds in the case of the fine fraction. The composition of the dust next to the construction was similar to the "usual" urban aerosol pollution, only it appeared in much higher concentrations. However, there were few exceptions. $P$ is typically natural element but in this case it appeared in the anthropogenic fraction with higher enrichment factor. In the fine fraction the concentration of $\mathrm{Pb}$ was usually under detection limit. However, one day, on 26. September we measured extremely high $\mathrm{Pb}$ concentration: $3255 \mathrm{ng} / \mathrm{m}^{3}$. The origin of this is not clear, one working phase could inject this high amount of lead into the atmosphere. In the case of the coarse fraction the $\mathrm{Pb} / \mathrm{Br}$ ratio was similar to that of the leaded gasoline, thus its origin could be the resuspended dust, despite the fact that leaded gasoline was not used for 15 years.

\section{Summary and conclusions}

In this study we have investigated the effect of a large scale construction work on urban aerosol pollution in the city of Debrecen, Hungary. We have compared the concentration data measured at several air quality monitoring stations situated at different distances from the construction. At the nearby station we have seen increase in both $\mathrm{PM}_{10}$ and $\mathrm{PM}_{2.5}$ concentrations, however, at the more distant stations no or negligible effect was detected in the $\mathrm{PM}_{10}$. In addition to the increase of the mass concentration, the contribution of $\mathrm{PM}_{2.5}$ increased significantly at the nearby sampling site for the years of the construction work. The seasonal variation of both the $\mathrm{PM}_{2.5}$ and the $\mathrm{PM}_{10-2.5}$ fractions changed too; it showed summer maximums during the period of the building. 
The elemental composition of atmospheric particulate matter did not change significantly, considerable increase in $\mathrm{Mn}, \mathrm{Cr}, \mathrm{Fe}$ and $\mathrm{Ni}$ concentrations was observed in our samples which could be attributed to the railroad building. However, at the construction site occasionally very high concentrations of heavy metals and toxic elements could be measured. In summary we can conclude that the effect of the tramline construction was local, did not expand to the whole city, only to about few streets nearby. However, those who lived or worked next to the construction were exposed to increased $\mathrm{PM}_{2.5}$ and $\mathrm{PM}_{10}$ levels with high heavy metal contents continuously for years.

\section{Acknowledgement}

This research was realized in the frames of TÁMOP 4.2.4. A/211-1-2012-0001, "National Excellence Program - Elaborating and operating an inland student and researcher personal support system convergence program". The project was subsidized by the European Union and co-financed by the European Social Fund.

This work was carried out in the frame of the János Bolyai Research Scholarship of the Hungarian Academy of Sciences.

This research was supported by the European Union and the State of Hungary, co-financed by the European Social Fund in the framework of TÁMOP 4.2.4. A/2-11-1-2012-0001 'National Excellence Program'.

\section{References}

[1] M. Amman, I. Bertok, J. Cofala, F. Gyarfas, C. Heyes, Z. Klimont, W. Schöpp, W. Winiwater, Baseline Scenarios for the Clean Air for Europe (CAFÉ) Programme,
Final Report. <http://www.iiasa.ac.at/rains/CAFE_files/Cafe-Lot1_FINAL(Oct). pdf>, 2005.

[2] N. Künzli, R. Kaiser, S. Medina, M. Studnicka, O. Chanel, P. Filliger, M. Herry, F. Horak Jr., V. Puybonnieux-Texier, P. Quénel, J. Schneider, R. Seethaler, J.-C. Vergnaud, H. Sommer, Lancet 356 (2000) 795-801.

[3] N. Mahowald, S. Albani, J.F. Kok, S. Engelstaeder, R. Scanza, D.S. Ward, M.G. Flanner, Aeolian Res. 15 (2014) 53-71.

[4] Gy. Varga, J. Kovács, G. Újvári, Analysis of Saharan dust intrusions into the Carpathian Basin (Central Europe) over the period of 1979-2011, Global Planet. Change 100 (2013) 333-342.

[5] Climate Change 2007 - The Physical Science Basis, Contribution of Working Group I to the Fourth Assessment Report of the IPCC, Susan Solomon, Dahe Qin, Martin Manning, Melinda Marquis, Kristen Averyt, Melinda M.B. Tignor, Henry LeRoy Miller, Jr., Zhenlin Chen (Eds.), Published for the Intergovernmental Panel on Climate Change, Cambride University Press, 2007.

[6] Ian M. Kennedy, Proc. Combust. Intstitute 31 (2007) 2757-2770.

[7] I. Ozga, A. Bonazza, E. Bernardi, F. Tittarelli, O. Favoni, N. Ghedini, L. Morselli, C. Sabbioni, Atmos. Environ. 45 (2011) 4986-4995.

[8] A. Wróbel, E. Rokita, W. Maenhaut, Sci. Total Environ. 257 (2000) 199-211.

[9] C.A. Belis, et al., European Guide on Air Pollution Source Apportionment with Receptor Models, Report EUR 26080 EN, JRC, European Union, 2014

[10] W. Maenhaut, F. Francois, J. Cafmeyer, The "Gent" stacked filter unit (SFU) sampler for the collection of atmospheric aerosols in two size fractions: description and instructions for installation and use, IAEA, Vienna, 1994, pp. 249-263. IAEA-NAHRES-19.

[11] Borbély-Kiss, E Koltay, S. László, Gy. Szabó, L Zolnai, Experimental and theroretical calibration of a PIXE setup for K and L X-rays, Nucl. Instr. Meth. Phys. Res., Sect. B 12 (1985) 496-504.

[12] Gy. Szabó, I. Borbély-Kiss, PIXYKLM computer package for PIXE analyses, Nucl. Instr. Meth. Phys. Res. Sect. B 75 (1993) 123-127.

[13] Gy. Szabó, PIXEKLM Program, User Guide, ATOMKI, Debrecen, 2009.

[14] Hungarian Central Statistical Office. <http://www.ksh.hu/docs/hun/xstadat/ xstadat_eves/i_met002b.html>.

[15] Hungarian Central Statistical Office. <http://www.ksh.hu/docs/hun/xstadat/ xstadat_evkozi/e_met002.html>.

[16] WHO Air quality guidelines for particulate matter, ozone, nitrogen, dioxide and sulfur dioxide, Global update 2005, Summary of risk assessment, WHO/ SDE/PHE/OEH/06.02. <http://whqlibdoc.who.int/hq/2006/WHO_SDE_PHE_ OEH_06.02_eng.pdf>. 